\title{
D. A. Obasa (1879-1945): a Yoruba poet, culture activist and local intellectual in colonial Nigeria
}

\author{
Akintunde Akinyẹi
}

\begin{abstract}
Introduction
One of the results of colonialism in Nigeria has been the evolution of a group of local intelligentsia with a discrete social identity. The nationalist and political activities of the group have received the attention of scholars. However, with a few notable exceptions (see Olabimtan 1974a; Ogunșina 1992), the same cannot be said of their contributions to the growth of literary tradition in Nigerian indigenous languages. This essay helps to fill that vacuum. The article hopes to contribute to the growing literature on local intellectuals in Africa. It examines the trilogy of a Yoruba poet, Denrele Adetimikan Ọasa, a member of the local intelligentsia in Ibadan, Nigeria (Figures $1 \mathrm{a}$ and 1b).

I begin with an overview of Obasa's biography and those factors that combined to shape him as a poet and local intellectual, because a meaningful discussion of his poetry demands such an examination. Then, the essay proceeds to discuss the social value in the poetry of Obasa, which, as revealed in the article, is based on the Yoruba world view and philosophical thought enshrined in the folkloric material that formed the basis of his poetry. The approach adopted in this study is multidisciplinary, combining historical analysis with sociological, cultural and philosophical perspectives.
\end{abstract}

\section{The poet and his background}

Denrele Adetimikan Obasa was born a prince of the Giessi ruling house of Ile-Ife in 1879 to Prince Awole Ọbasa and his wife Fọlawiyọ, who were working in Lagos at the time of their son's birth. After his elementary (primary) school education (1886-90), the young Obasa gained admission into the Baptist Academy in Lagos in January 1891, and successfully completed his high school education in December 1896. Due to his parent's limited financial resources, Obasa could not travel overseas for his post-secondary education, like some of his contemporaries from wealthy families. During this time, there were no post-secondary institutions in Nigeria: the first ones to be established came fifty years later, with the foundation of Yaba Higher College (now Yaba College of Technology) in Lagos in 1947 and the University College Ibadan (now the University of Ibadan) in 1948. So, Obasa decided to apply for positions with companies based in Lagos. But, while he waited for a job offer, Obasa's parents advised him to learn some form of trade. Opbasa agreed, and he signed up as an apprentice with a local

\footnotetext{
Akintunde Akinyemi is a Professor in the Department of Languages, Literatures, and Cultures at the University of Florida in Gainesville. Email: akinyemi@ufl.edu
}

(C) International African Institute 2017 
(a)



(b)

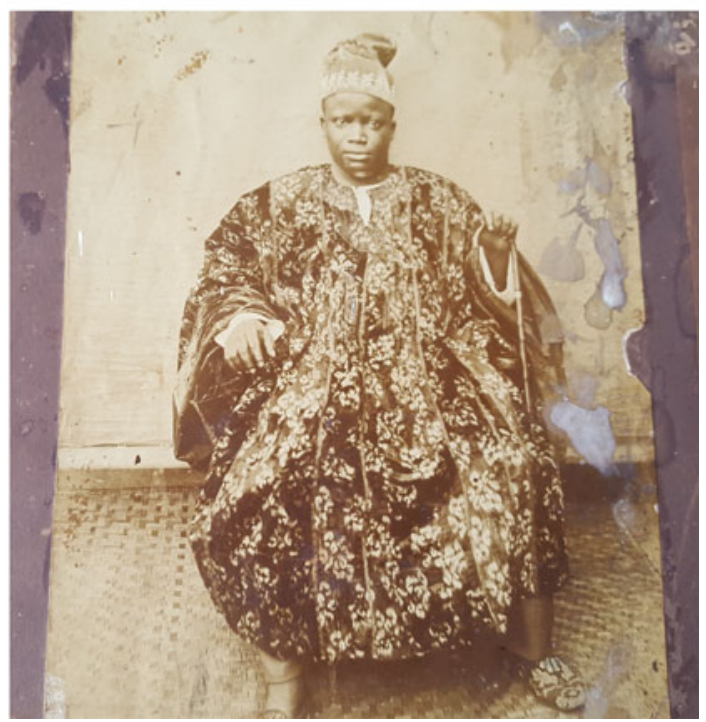

FIGURE 1 Denrele Adetimikan Ọbasa.

printing press and a furniture maker in Lagos. Although Obasa successfully completed his training in both, he loved the printing press more; that probably accounted for his decision to establish a printing press later in life.

Ọbasa learned the art of editing, printing and publishing in Lagos under a Sierra Leonean Yoruba ex-slave returnee, Mr G. A. Williams. Obasa dedicated a substantial section of the poem İkíni ('Homage' or 'Greetings') in his first book of poetry to the role $\mathrm{Mr}$ Williams played in his training as an editor and printer:

İbà tí mo júun t'ọgáà mi ni:

Ògbẹni G. A. Williams onínúure!

Editor àgbà n'Ílé-Èkó ...

Òu l'ó kọ mi n'ịsẹe,

Tí mo fi ǹ jẹn:

Ni mo fi joyè Editor,

S'Ílé İbàdàn Mesì Ògọ. ${ }^{1}$
That homage is for my boss:

Mr G. A. Williams, the good man!

The renowned editor in Lagos ...

He taught me the art [of the printing press], That I live on today.

In my present position as the Editor [of the Yoruba News]

In Ibadan, the great city.

Ọbasa was nearing the end of his training in printing and carpentry when he received his first job offer in December 1899 as a sales manager with Paterson Zochonis (PZ) in Lagos, a British-owned company and manufacturer of healthcare products and consumer goods founded in 1879. Ọbasa was later transferred

\footnotetext{
19 Obasa (1927: 3). See ‘Two Poems by D. A. Ọbasa’ below.
} 


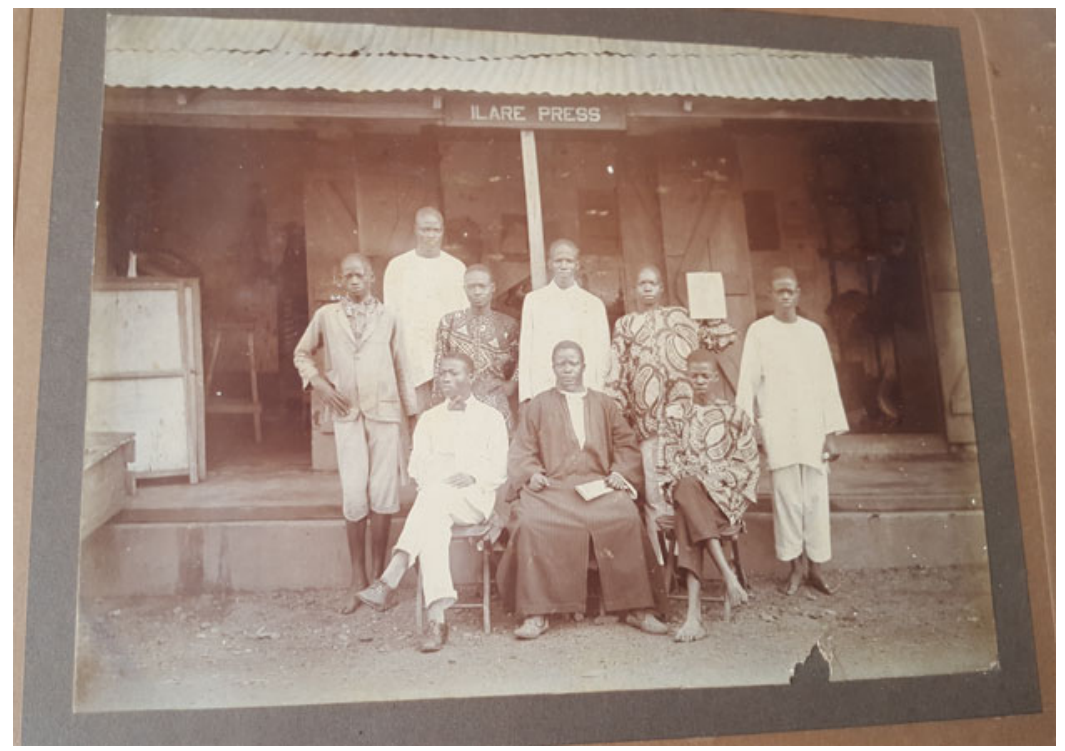

FIGURE 2 Ọbasa and his workers and apprentices at Ilarẹ Printing Press.

to Ibadan in December 1901 as the store manager for the newly opened branch office of the company. He remained in the Ibadan branch office until December 1919, when he resigned after twenty years of unbroken service, to establish his Ilarẹ Printing Press (Figure 2).

Obasa's choice of Ibadan as the location of his printing press was strategic none of the other printing press companies already in existence in Nigeria had an office in Ibadan. They were all based in Lagos and Abeokuta. So, with the opening of Ilare Printing Press in Ibadan, Obasa was able to draw patronage from Ibadan and other major Yoruba cities. The press flourished and became well known, because of Obasa's multidisciplinary qualities as creative writer, public intellectual, businessman, news editor, advertiser, and above all artisan. All this affected his popularity as a writer and the success of his printing business. Later, other printing press companies were founded: for example, Lisabi Press in Ibadan in 1930 and Tanimẹhin-Ọla Press in Oṣogbo in 1935. It was in the midst of the competition from other printing companies and deteriorating health that Ọbasa died on 16 May 1945.

What are those aspects of Obasa's biography that make him an outstanding Yoruba poet and local intellectual? One can say that the greatest influence on Ọbasa by far was his love for, and interest in, Yoruba language and cultural practices. Obasa perceives his task as "that of "writing culture", writing the oral traditions and the language of his people to recover an art and knowledge that he felt to be endangered' (Nnodim 2006: 158). For that singular act, this essay recognizes Obasa as a public intellectual within the colonial Yoruba cultural environment because he strategically chose to write in Yoruba instead of English, as he wanted to address his immediate local audience. 
Although Obasa was championing the cause of Yoruba language and the preservation of oral traditions, he was, however, doing so in print, which meant that he had to find ways of connecting with an audience that was not co-present. According to Nnodim (2006: 154):

the issue of turning towards, giving shape to, and addressing audiences was particularly pertinent at those pivotal historic trajectories, when the introduction of writing, print technology and electronic mass media enabled verbal artists (and early writers) to go beyond the local towards conceptualizing and addressing potentially unlimited, unknown audiences (and readers) through print expression and through a new kind of mass-mediated secondary orality.

Thus, in the case of Obasa, the delivery of his poems in print did not engender hegemony of the written word and did not displace the oral as an obsolete mode of literary expression; rather, it opened up possibilities for numerous creative forms of coexistence and interfaces of the oral and the written. Therefore, Obasa, through print technology, was able to connect with his audience through a form of poetic expression that is semi-oral and semi-written, a type of genre that oscillates between the written and the oral.

Because Obasa's poetry is situated at the intersection of writing and orality, the audience he addresses in some of his poems is a thoroughly local one, interpolated in his poems through a proliferation of local terms of greeting:

Àgò o! Àgò o!! Àgò o!!!!

Onílé mo kágò

Kín tó wolé.

Ewúré wolé kò kágò,

Ni wọ́n bá mú un so;

Àgùtàn wọlé kò kágò,

Ni wọn bá mú un so,

Àgbà t'ó wọlé tí kò kágò

Ó di mímú so! ${ }^{2}$
Homage! Homage!! Homage!!!

I pay necessary homage to the homeowner

Before I enter.

A goat that enters the house without paying homage,

Opens itself to entrapment [or leashing or tethering to the post];

A sheep that enters the house without paying homage, Opens itself to entrapment [or leashing or tethering to the post],

Any adult that enters the house without paying homage Opens him- or herself to entrapment [or leashing or tethering to the post]!

In this excerpt, the encounter between Opasa and his audience is 'metaphorically imagined as "knocking on people's doors", as seeking for permission to enter' (Nnodim 2006: 159). He addresses an imaginary audience directly with his interpolation of face-to-face greetings directed at different sets of people in society. In other instances, however, he envisions a larger audience, seeking his audience not only among the different sub-groups or dialects of the Yoruba with whom he inhabits the shared space called Yorubaland, but among other languages whose speakers are found in that same society.

Oyinbo ni, 'Who is that?' The white man says, 'Who is that?'

Ėkó ní, 'İwo ta nì yẹn?' The Lagos-Yoruba speakers say in Lagos dialect, 'Who is that?'

\footnotetext{
${ }^{2}$ Obasa (ibid.: 1). See 'Two Poems by D. A. Obasa' below.
} 
'İwo ọmo lèsí yẹn wà?' Ègbá ní, 'Lè é ìyẹn?'

İjẹbú ní, 'Lès'óun wá?'

İjẹșà ni, 'İwo yèsí?'

Ifẹ ní, 'İwo yèsí ré ni?'

Òyọ́ ní, 'İwo ta'a nì i nì?'

Ègùn ní, 'Ménùwẹ??'

Hausa ní, 'Wò ní nì?'

İbàdàn ní, 'İwo ta nù-un?'3
'Whose child is that?'

The Ėgbá-Yoruba speakers say in Ègbá dialect, 'Who is that?'

The İjẹ̀bú-Yoruba speakers say in İjẹbú dialect, 'Who is that?'

The İjẹșà-Yoruba speakers say in İjẹsàa dialect, 'Who is that?'

The Ifẹ̀-Yoruba speakers say in Ifẹ̀ dialect, 'Who is that?'

The Ộyọ-Yoruba speakers say in Ọyọ́ dialect, 'Who is that?'

The Ėgùn speakers say in their language, 'Who is that?' The Hausa speakers say in their language, 'Who is that?'

The İbàdàn-Yoruba speakers say in İbàdàn dialect, 'Who is that?'

Here, Obasa is trying out numerous ways of addressing an imagined audience, in numerous languages and dialects. This demonstrates not only a wish to connect directly with a large audience of readers in a quasi-oral fashion, but also a recognition that his own language and language variant (Oyọ or Ibadan Yoruba) was among many: a cosmopolitan perspective. And Obasa shows off his cosmopolitan credentials and linguistic proficiency by presenting greetings in all of them, with great expertise too.

Obasa's choice of Yoruba language for his writing assisted him in connecting with the generality of the people in his locality, and he became very popular. That popularity paid off when his books were included in the reading list for public elementary schools in the Yoruba-speaking region of south-western Nigeria. Obasa's books fit well into the early childhood education curriculum because, as a poet, the writer was concerned with instilling moral values in children and young adults, using his poems to instruct and correct, with the ultimate aim of promoting acceptable good conduct in society.

Because of Obasa's commitment to Yoruba culture and tradition, he made a clear case in the prologue (İjúbà) to the first collection in his trilogy for the study of the oral artistic traditions of the Yoruba people, which he claimed were comparable to the works of renowned authors such as Homer (the Greek poet), Longfellow (the American poet) and Shakespeare (the British poet and playwright):

Púpọ̀ nínú wọn (ohùn ẹnu Yorùbá) li ó farajọ ti awọn àròfọ̀ àwọn ọjọgbộn ti ilú òibó tí a ńn kọni ní àwọn ilé-ẹkọ́ wa: gẹgẹ bii "Homer," "Longfellow," "Shakespeare" àti àwon mi bẹbẹ

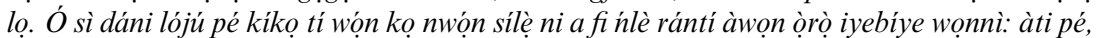
kò sí ohun tí ó ye wá bi orilè-èdè bíi pé kí a ko tiwa náà sílè fún ànfàní àwọn ènià wa àti ìran tí mbò. ${ }^{4}$

Many Yoruba oral genres are similar to the ones we read in school such as the works of Homer, Longfellow, Shakespeare, etc. There is no doubt that it was because they were written down that these invaluable compositions can be remembered. Therefore, nothing befits us as a nation other than for us to document our own [oral] literature for the coming generations.

\footnotetext{
${ }^{3}$ Obasa (ibid.: 1-2). See 'Two Poems by D. A. Ọbasa' below.

${ }^{4}$ Ọbasa (ibid.: 1).
} 
Earlier, in 1896, Obasa had embarked on the systematic collection of Yoruba folkloric materials. As he stated in the same prologue cited above:

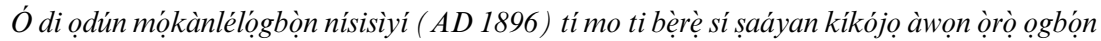
àtaiyébáiyé ti àwọn baba ńlá wa, tíl máa hàn jáde nínú orin, ègè, rárà, ìjálá, ìpẹsà, àròfọ̀, oríkì, ilù, fèrè àti àgbékà ọrọ̣ won. ${ }^{5}$

For the past thirty-one years (1896-1927) I have been documenting Yoruba traditional sayings which embody the wisdom of our forefathers. These sayings are found in songs, and in various forms of Yoruba poetry, ègè, rárà, ijálá, ìpẹsà, àròfộ, oríkì, and in the drum language and the flute.

But Ọbasa's greatness as a poet is not restricted only to the collection and publication of traditional sayings, which embody the traditional wisdom of the Yoruba people, although, in Obasa's time, this would have stood as a singular achievement on its own. As is well known, several authors were doing just that: Agbebi had collected and published Yoruba riddles in 1885; Lijadu had collected and published Ifá divination verses in 1897 and 1908 and had helped publish the poems of two Egba-Yoruba bards, Aribiloṣo and Șobọwale Șowande (better known as Sobọ Arobiodu) in 1902 and 1906 respectively; while, in 1911, Akinyẹle had published his own valuable book, İwé ìtàn İbàdàn, İwó, İkìrun, àti Òsogbo, which contained many personal and lineage oriki. However, none of these earlier writers had made use of as many forms of Yoruba oral poetry in their works as Obasa. Even so, Obasa declares in his poem İkini that his role is more than that of a scribe recording traditional sayings; he is also a poet in his own right:

Èmi l'Akòwé Akéwì,

Ėmi l'Akéwì Akòwé.

Bí mo ti n ké kíké

Bẹè náà ni mo ń ko kíko!

Emi a sì máa tè l'ótìtẹ. ${ }^{\dot{\sigma}}$
I am the [oral] poet's scribe,

I am the literate poet;

As I chant what is to be chanted

I also write what is to be written

And I print what is to be printed.

With this self-imagination as a poet, Obasa appeals to a figure that was paradigmatic for the local intellectuals of his day who sought to transpose into writing the oral art of their people. But he also perceives himself as a performing poet located on a continuum between the oral and the written - chanting, writing and printing. Therefore, Obasa's greatness as a poet lies in his use of Yoruba oral poetic features and style to produce written poetry at a time when many writers of Yoruba poetry were being influenced by English poetic styles. ${ }^{7}$ As rightly noted by Babalọla and Gerard (1971: 121), it was Obasa who provided the 'link between traditional beliefs and writing in the modern vein' and therein lies his greatness as a poet and local intellectual.

\footnotetext{
${ }^{5}$ Ọbasa (ibid.: 1).

${ }^{6}$ Öbasa (ibid.: 2). See 'Two Poems by D. A. Obasa' below.

${ }^{7}$ This group of poets (A. K. Ajisafe, Afọlabi Johnson and others) uses the English poetic style to compose Yoruba poems. They were not necessarily translating English poems into Yoruba. Rather, they concentrated more on the rhythm of the poems than on the principal characteristic features of Yoruba oral poetry, such as tonal counterpoint, parallelism, repetition, metaphor and figurative expressions (Ọlatunji 1984: 17-58).
} 
Olabimtan (1974b: 1034) identifies three broad categories for Obasa's poems: (1) those which have Obasa's original composition joined to strings of traditional sayings; (2) those which are Obasa's original compositions on select, traditional sayings; and (3) those which are strings of traditional sayings selected from oral materials with little or no addition from Ọbasa. For example, in the poem İkà-Èké ('Treachery and Wickedness') in Book One, there are seven proverbs in the first twenty-five lines; while lines 40-43 sound more like ijálá chant; and lines 36-39 and 61-64 are utterances traditionally beaten out on dùndún talking drums. With a poem like this, ${ }^{8}$ one may feel that Obasa is no more than a mere collector of 'traditional Yoruba sayings of proverbial type' (Babalọla and Gerard 1971: 121). Even so, Obasa deserves credit for looking for oral materials appropriate to the title of the poem and for arranging them in a way that creates a poetic flow with the language.

While the poem İkà-Ėké is representative of Obasa's early poems that are strings of traditional sayings, a number of his other poems, mostly in Books Two and Three, include the poet's personal compositions, evidence of his development as an original artist with a voice of his own. These are of two types: those in which Obasa's original composition is mixed with strings of traditional sayings; and those that are entirely Obasa's original compositions. Examples of the first type are the poems İkíni in Book One and İkíni Akéwì II ('The Poet's Greetings II') in Book Two, while the poems Àntí Onílà ('The Lady with Facial Scarification') and İlù Sójà ('The Rhythm of the Military Parade Band') ${ }^{10}$ in Book Two and Alásejù ('One Who Acts in Excess' $)^{11}$ in Book One are clear examples of the second type.

The poem Alásejù is one of the most fascinating poems, in which Ọbasa exhibits his creativity as a poet with a voice of his own, and a unique style of writing that relies minimally on oral material. Obasa not only shows off his originality as a poet in the poem, but he also exhibits his awareness of addressing a larger audience. For example, for most of the poem, Obasa concentrates on two major political issues - the power tussle between the British and German leaders in Europe, and the civil disobedience or religious war led by Shaykh Sai'd Hayyat, a Mahdiyya follower in Northern Nigeria (see Saeed 1992).

Ọbasa's success as a local intellectual and poet was enhanced and consolidated by several special factors: (1) his membership of the socio-cultural group Egbẹ Àgbà ò Tán (Elders Still Exist Society), formed in Ibadan in 1909; (2) the establishment of Ilare Printing Press; and (3) the publication of the weekly Yoruba newspaper Yoruba News.

From the late nineteenth century onwards, some Yoruba culture activists founded a number of socio-cultural organizations, including Egbẹ Àgbà ò Tán, which played a major role in establishing in the collective psyche of the people a sense of their own importance in the colonial system. ${ }^{12}$ These culture activists

\footnotetext{
${ }^{8}$ For this poem and three others of the same type, see sections A $1-4$ in the supplementary material published with this article: 'Nine poems by D. A. Obasa, with English translations by Akintunde Akinyẹmi', <https://doi.org/10.1017/S0001972016000668>.

${ }^{9}$ For this poem, see section B 6 in the supplementary material.

${ }^{10}$ For these two poems, see sections $\mathrm{C} 7$ and $\mathrm{C} 8$ in the supplementary material.

${ }^{11}$ See 'Two Poems by D. A. Obasa' below.

${ }^{12}$ Others are Egbẹ Olùfẹ́ Ilẹ İbí Wọn (Society for the Lovers of their Birth Place), formed in Abẹokuta in 1883, and Egbẹ́ Onífẹe ìlẹ Yorùbá (Society for the Lovers of Yorubaland), formed in Lagos in 1907.
} 
thus assumed the role of community leaders or elders who acted as cultural brokers between indigenous socio-political paradigms and the novel creations of the colonial state. As a social group, this local intelligentsia had a distinct lifestyle that embraced Western ways and values in addition to their own Yoruba heritage. Therefore, the organizations they formed were also positive agencies of internal development and served to uphold the morale of the community during the experience of colonial rule.

Obasa, having relocated from Lagos in 1901, was a founding member of the Egbẹ Àgbà ò Tán at its inauguration in 1909 in Ibadan (Ọlabimtan 1974a: 30). The association was concerned particularly with the promotion of a literary culture through periodic public lectures on issues relating to Yoruba history and culture. For several years, Obasa read excerpts from his poems at the association's monthly meetings. The association's publication committee encouraged Obasa to publish his poems, but he had a different plan: to publish the first Yoruba weekly newspaper in Ibadan and to include excerpts of his poems in the newspaper (Akinyẹmi 1987: 62).

Thus, on 15 January 1924, Obasa published the first issue of Yoruba News, a weekly newspaper that reported local developments in Yorubaland. On 12 February 1924, he started what became a regular feature in Yoruba News: the publication of excerpts of his poems in the column 'Àwọn Akéwì or Yoruba Philosophy' (Figure 3). The table below reveals that Obasa published in Yoruba News all but two of the twenty-nine poems in İwé Kḯní Ti Àwọn Akéwì (Yorùbá Philosophy) between 25 March 1924 and 10 August 1926, several months before the publication of the book of poetry itself in 1927.

\begin{tabular}{|c|c|c|}
\hline No. & $\begin{array}{l}\text { Title of poem in Book One } \\
\text { (listed in order } \\
\text { of their publication in Yoruba } \\
\text { News) }\end{array}$ & Date of publication in Yoruba News \\
\hline 1. & Pẹlẹpẹlẹ ('Gently, with Care’) & $\begin{array}{l}25 \text { March } 1924 \text { (republished on } 15 \\
\text { September } 1925 \text { and } 22 \text { September } \\
\text { 1925) }\end{array}$ \\
\hline 2. & Mọ́kánjúọlá ('Patience’) & 25 March 1924 \\
\hline 3. & $\begin{array}{l}\text { Erè-Isé ('Reward of Hard } \\
\text { Work') }\end{array}$ & $\begin{array}{l}1 \text { April } 1924 \text { (republished on } 27 \text { July } \\
\text { 1926) }\end{array}$ \\
\hline 4. & $\begin{array}{l}\text { Elétò-Ètò ('Doing the Right } \\
\text { Thing') }\end{array}$ & $\begin{array}{l}8 \text { April } 1924 \text { (republished on } 27 \text { July } \\
\text { 1926) }\end{array}$ \\
\hline 5. & $\begin{array}{l}\text { Aláigboràn ('The Disobedient } \\
\text { One') }\end{array}$ & 15 April 1924 \\
\hline 6. & $\begin{array}{l}\text { Aláșejù ('One Who Acts in } \\
\text { Excess') }\end{array}$ & $\begin{array}{l}15 \text { April } 1924 \text { (republished on } 22 \text { April } \\
1924 \text { and } 29 \text { April 1924) }\end{array}$ \\
\hline 7. & Àgbèrè ('Adultery') & 5 May 1924 \\
\hline 8. & Ogbộn Àgbọnnjù ('Caution!') & 13 May 1924 \\
\hline 9. & İlara ('Envy’) & 27 May 1924 \\
\hline 10. & Omo ('The Child') & 27 May 1924 \\
\hline 11. & $\begin{array}{l}\text { İkà-Eké ('Treachery and } \\
\text { Wickedness') }\end{array}$ & 24 June 1924 \\
\hline 12. & $\begin{array}{l}\text { Eye ('Knowing What is } \\
\text { Desirable') }\end{array}$ & 15 July 1924 \\
\hline
\end{tabular}




13. À̀̀goràn ('Disobedience')
14. İtànje ('Deceit')
15. Ẹdá ('Destiny')
16. Oagbọn ('Intelligence')
17.

18. İkini ('Homage'/'Greetings')

19. Oore ('Kindness')

20. Ebi ('Hunger')

21. İyàn Yánmororo ('Acute Famine')

22. Ète ('Beguilement')

23. Àtara-ẹni-rò ('Being Considerate')

24. Kí la ti máa șe é? ('What Should We Do?')

25. Ayé Òdájú ('Callousness')

26. Oníwọra ('The Greedy')

27. İbàjẹ ('Treachery')

28. Pagidarì ('Unpredictability')

29. İyàn Eléfẹẹ ('Mild Famine')
15 July 1924

15 July 1924

5 August 1924 (republished on 14 September 1926)

5 August 1924 (republished on 14 September 1926)

26 August 1924 (republished on 23 November 1926 and 30 November 1926)

2 September 1924

9 September 1924

17 February 1925

3 March 1925

27 April 1926 (republished on 4 May 1926)

6 July 1926 (republished on 13 July 1926)

20 July 1926

27 July 1926

3 August 1926

10 August 1926

Not pre-published in the Yoruba News Not pre-published in the Yoruba News

On 4 November 1924, Ọbasa began an aggressive weekly ad campaign to promote his first book of poetry in Yoruba News (Figure 4). Some of the marketing strategies Obasa adopted to promote his yet-to-be published book of poetry included: (1) the adoption of the heading of the column 'Àwọn Akéwì or Yoruba Philosophy', under which he published excerpts of his poems in Yoruba News, as the title of the book; (2) the addition of his position as editor of the Yoruba News to his name as the author; and (3) the listing of the publisher as his Ilare Printing Press, Ibadan. Thus, by 'signing his autograph' on the cover page of his poetry book as 'Denrele Adetimikan Obasa, Editor of the "Yoruba News," Ibadan; Published by Ilare Press, Ibadan', Obasa created a link between his book of poetry and the diverse identities he already asserted in society. Drawing on a multiplicity of roles - poet, culture activist, newspaper columnist, printer, publisher, newspaper editor and reporting journalist - enabled Obasa to exhibit the diverse identities that he constructed for himself and to assert his prominence within the circle of the local intellectuals in Yorubaland at that time. These strategies contributed in no small way to the publicity surrounding the book and its acceptability among local readers of the Yoruba News.

\section{The social value of Obasa's poetry}

Obasa deserves credit for popularizing a vision of poetry that assigns it definite social value, especially in its utility in instructing, correcting and influencing conduct. This 


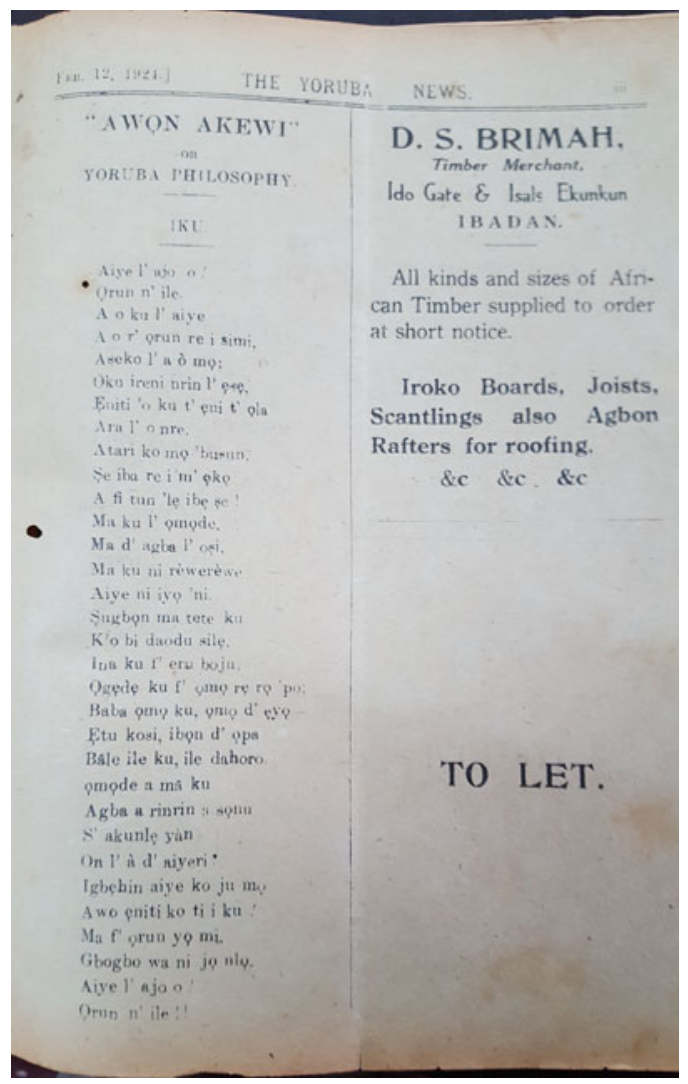

FIGURE 3 Obasa's first published poem in the Yoruba News of 12 February 1924, entitled $I k u ́$ ('Death').

implies that Obasa is placed on an elevated moral platform that enables him to use his poetry to inform, correct and educate his readers. This is exemplified by unique didactic precepts from Yoruba oral literature inscribed in many of Obasa's compositions.

One major issue given prominence in Obasa's poetry is the value that the Yoruba attach to children. The child is presented in a number of Obasa's poems as the axis around which the entire life of the Yoruba rotates. This is especially evident in the poems Omo ('The Child') and Òle ('Laziness') in Book One; Erú ('Slaves'), Akéjù ('The Spoilt Child'), Òmùgọ̀ ('The Stupid One'), Omo, Apá Kejì ('The Child, Part 2') and İwà ('Character'), all in Book Two.

Yoruba traditional education is entirely invested in character building. According to Awoniyi (1975: 375), 'nothing mortifies a Yoruba more than to say that her or his child is "àbiikoọ" [a child who is born but not taught]. A child is better "àkóọgbà" [a child who is taught but who does not learn], where the responsibility is that of the child and not her or his parents.' Obasa (1934: 3940) reiterates this point in the poem Àigbọn ('Stupidity') in Book Two: 


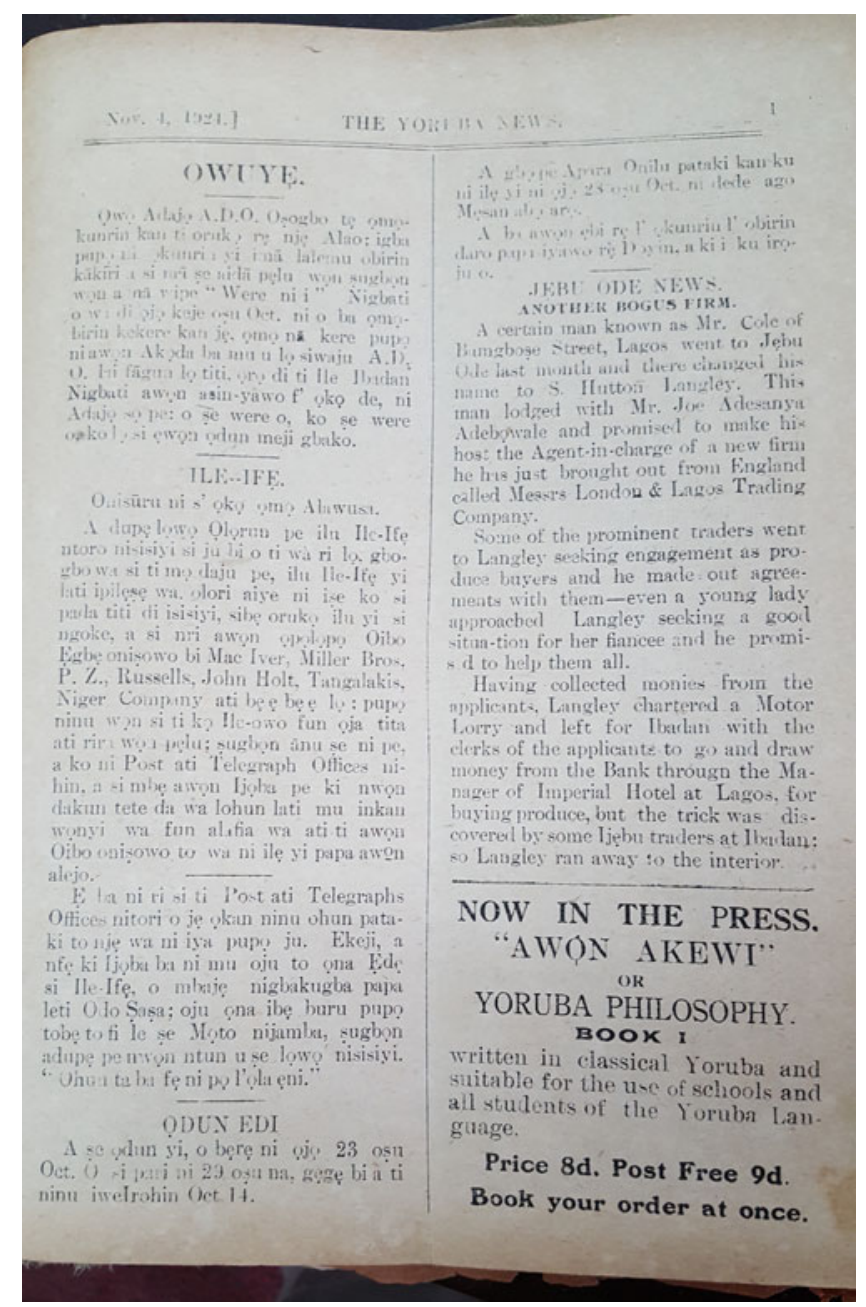

FIGURE 4 The first advert for Book One of Obasa's trilogy in the Yoruba News of 4 November 1924.

\author{
Àbí-ikọ làkọọ̀gbà, \\ Omọ tí kò gbọn nílé, \\ Kì í mọ̀ràn lájò.
}

A child who is not taught is no different from the one who refuses home training,

A child who rejects home training,

Should not be expected to act intelligently outside.

Different types of oral poetry or songs with themes designed to deter children from bad habits are employed in Yoruba society as effective means of encouraging good behaviour in children. Several of these qualities are addressed in a number of 
Obasa's poems. For example, while counselling his readers to be kind to others in the poem Oore ('Kindness'), Obasa (1927: 6) projects the Yoruba philosophy that says 'Towó-tomo ní yalé olóore' ('All good things come the way of those who show kindness to others') and 'Kòni gbàgbé loore é jẹ’' ('No one forgets any kindness shown to him or her'). Similarly, the poem Baba ('Father, First Among Equals') refers to the value placed on seniority or primacy by the Yoruba. In the poem, Obasa (1934: 26) recalls the popular saying 'Émí àbàtà níi mu odò șàn, ọláa baba ọmo níi mu omọ yan' ('The stream relies on the surrounding wetlands for its survival; every child benefits from his or her father's reputation'). ${ }^{13}$ In the poem Mókánjúọlá ('Patience'), Obasa (1927: 14) counsels his readers not to be in too much of a hurry; instead, they are encouraged to wait on God: 'Atọrọ ohun gbogbo lọwó Olọrun kì i kánjú' ('Those who wait on God are never in a hurry'). Also, in Elétò-ètò ('Doing the Right Thing'), Obasa (ibid:: 52) admonished his readers to be conscious of their individual limitations, using the restrictions in the scope of the circumciser and butcher as metaphors to drive home his point: 'Oníkọlà ki i k'àfín; kò s'álápatà tíi pa'gun' ('No circumciser circumcises an albino; no butcher attempts to kill the vulture'). ${ }^{14}$ And, in the poem Pẹlépẹlẹ ('Gently, with Care'), Ọbasa (ibid.: 13) encourages his readers to handle every issue with patience and extra care: 'Ohun a fẹsọ mú kì í bàjẹ; ohun a f'agbára mú koko-ko ní i le!' ('Whatever we handle with great care ends well; but whatever we mishandle becomes a difficult task to achieve'). ${ }^{15}$

In a similar vein, Obasa identifies many social vices in his work, which he condemns in several of his poems while admonishing his readers to avoid such negative attitudes. For instance, in Book One, Obasa condemns disobedience to constituted authorities in the poem Alásejù, envy in İlara, guile in Ète, deceit in İtànjẹ, treachery and wickedness in İkà-E் $k e ́,{ }^{16}$ callousness in Ayé Ọdájú, and adultery in the poem Alágbèrè. In Book Two, he also counsels his readers not to pay lip service to friends in the poem İfẹ Etè, not to disrespect others in $\grave{A} f o j u ́ d i$, not to tell lies in Irọ, not to backbite in Ộọ Éhìn, and to avoid doubletalk in the poem Elénu Méjì. Thus, one can use Ọasa's poems to discover the value the Yoruba attach to the things they desire or the things they wish to avoid.

\section{Conclusion}

This article has examined one of the ways in which oral poetic forms were employed by early Yoruba writers. This implies a determination on the part of writers such as Obasa to sustain the communicativeness of oral literature in the written medium, thereby transferring the oral material beyond the limitations of its written quality to speak as the oral text does to the audience. As revealed in the above discussion, the revitalization of oral traditions, particularly through the poetry of Obasa, does not arise from a nostalgic longing for local folkloric

\footnotetext{
${ }^{13}$ For this poem, see section A 4 in the supplementary material.

${ }^{14}$ For this poem, see section A 2 in the supplementary material.

${ }^{15}$ For this poem, see section A 1 in the supplementary material.

${ }^{16}$ For this poem, see section A 3 in the supplementary material.
} 
colour. Rather, it reintroduces the Yoruba oral literary form to create a popular poetic language that can be shared with the generations yet unborn.

Writing from his ethnic base, Obasa exploited communal oral resources for ideas, themes and other linguistic influences. In so doing, he participated in the global literary trend of intertextuality, which Abrams (1981: 200) defines as a creative means used to

signify the multiple ways in which any one literary text echoes, or is inescapably linked to other texts, whether by open or covert citations and allusions, or by the assimilation of the feature of an earlier text by a later text, or simply by participation in a common stock of literary codes and conventions.

Thus, in his poems, Obasa transformed oral traditions into metaphorical and symbolic language that best articulated his political or philosophical positions. This suggests that orality is not static but dynamic, flexible, and adaptable to change. As such, oral traditions must be viewed as an integrative, and even innovative, force allowing for new forms of expression. In short, the phenomenon of orality - and its corresponding modes of communication - was effectively modernized by Obasa, reflecting the attainment of sophisticated levels of signification and synthesis. This development of fresh mechanics for modern literature is relevant, valuable, and a major part of the achievement of the literary creations of contemporary writers.

\section{Acknowledgements}

To the two anonymous peer reviewers who provided insightful comments and helpful recommendations in their reports on the early version of this article, I offer my deep gratitude. I also wish to express my appreciation to two of Obasa's grandchildren - Mr Samuel Babatunde Obasa and Mr Alfred Adekanmi Obasa - for providing the three photographs of Ọbasa included in this article.

\section{Supplementary material}

Supplementary material is available with the online version of this article at <https://doi.org/10.1017/S0001972016000668>. This includes nine poems by D. A. Obasa with English translations introduced and annotated by Akintunde Akinyẹmi.

\section{References}

Abrams, M. H. A. (1981) A Glossary of Literary Terms. 3rd edition. New York NY: Holt, Rinehart and Winston, Inc.

Akinyẹmi, A. (1987) 'Adénrelé Adéètìmíkàn Ọbasá (1927-1945): akéwì aláròjinlè̀'. MA thesis, University of Ifẹ, Nigeria.

Awoniyi, T. A. (1975) 'Omolúàbí: the fundamental basis of Yorùbá traditional education' in W. Abimbọla (ed.), Yoruba Oral Tradition: poetry in music, 
dance, and drama. Ile-Ifẹ, Nigeria: Department of African Languages and Literatures, University of Ifẹ.

Babalola, A. and A. Gerard (1971) 'A brief survey of creative writing in Yoruba', Black Africa 2: 113-25.

Nnodim, R. (2006) 'Audiences in Yoruba novel, print and media poetry', Research in African Literatures 37 (3): 154-75.

Ọbasa, D. A. (1927) İwé Kì́ní Ti Àwọn Akéwì. [Yoruba Philosophy.] Ibadan, Nigeria: Ilare Press.

Ọbasa, D. A. (1934) İwé Kejì Ti Àwọn Akéwì. [Yoruba Philosophy.] Ibadan, Nigeria: Ilare Press.

Ogunșina, B. (1992) The Development of the Yoruba Novel c. 1930-1975. Ilorin, Nigeria: Gospel Faith Mission Press.

Olabimtan, A. (1974a) 'A critical survey of Yoruba written poetry, 1848-1948'. PhD thesis, University of Lagos, Nigeria.

Ọlabimtan, A. (1974b) 'Language and style in Obasa's poetry' in W. Abimbola (ed.), Yoruba Oral Tradition: poetry in music, dance, and drama. Ile-Ife, Nigeria: Department of African Languages and Literatures, University of Ifẹ.

Ọlatunji, O. (1984) Features of Yoruba Oral Poetry. Ibadan, Nigeria: University Press Limited.

Saeed, A. G. (1992) ‘A biographical study of Shaykh Sai’d Hayyat (1887-1978) and the British policy towards the Mahdiyya in Northern Nigeria, 19001960'. PhD thesis, Bayero University, Kano, Nigeria.

\begin{abstract}
This article examines the works of one of the earliest Yoruba poets, Denrele Adetimikan Obasa (1879-1945), a member of the local intelligentsia in colonial Nigeria. In my assessment of the poet as a culture activist and local intellectual, I draw on biographical information, extensive archival research and relevant textual illustration. The central argument of the article is that Obasa exploits Yoruba communal oral resources for ideas, themes and other linguistic influences in his poetry. Therefore, the essay explores the creative ability of Obasa to preserve different forms of oral literary material in his poetic composition and how he uses the folkloric materials as instruments for raising the social consciousness of his readers. At this level, the article argues, Obasa transforms oral traditions into metaphorical and symbolic language that best articulates his political or philosophical positions. Thus, orality is not static, but dynamic, flexible and adaptable to change. The main article offers translations of excerpts from Obasa's poetry, while the online supplementary material offers more complete samples of Obasa's poems.
\end{abstract}

\title{
Résumé
}

Cet article examine l'œuvre de l'un des tout premiers poètes yoruba, Denrele Adetimikan Ọbasa (1879-1945), membre de l'intelligentsia locale du Nigeria colonial. Dans son évaluation de ce poète en tant qu'activiste de la culture et intellectuel local, l'auteur s'appuie sur des données biographiques, de nombreux travaux d'archives et des illustrations de texte pertinentes. L'argument central de l'article est le fait qu'Ọbasa exploite les ressources orales communales 
yoruba pour inspirer les idées, les thèmes et autres influences linguistiques de sa poésie. L'essai explore donc la capacité créatrice d'Obasa à préserver différentes formes de matériel littéraire oral dans sa composition poétique et la manière dont il instrumentalise le matériel folklorique pour éveiller la conscience sociale de ses lecteurs. L'article soutient qu'à ce niveau, Obasa transforme les traditions orales en langage métaphorique et symbolique qui exprime au mieux ses positions politiques ou philosophiques. L'oralité n'est donc pas statique mais dynamique, flexible et adaptable au changement. L'article principal propose des traductions d'extraits de la poésie d'Ọbasa, tandis que le matériel supplémentaire en ligne offre des exemples plus complets des poèmes d'Ọbasa. 